\author{
Sergej Macura* \\ University of Belgrade, Serbia
}

\title{
A SURVEY OF THE ITALIAN COMMUNITY IN TORONTO IN THE POSTMODERN AGE
}

\begin{abstract}
The paper briefly covers the most important stages in Italian immigration to the Toronto area, beginning with the second half of the $19^{\text {th }}$ century, and ending with the early $21^{\text {st }}$ century. It includes the main neighbourhoods and their spread to the northwest, as the three waves of migration brought new population groups into Canada up to 1914, in the 1920s and between 1950 and 1970. Certain issues that the Italians faced are brought to light, like poor housing and employment in manual jobs; on the other hand, their resilience is reflected in strong family ties that kept them together, which ultimately enabled the creation of many construction companies. In addition, the women played an important part in emancipating themselves when they joined the workforce in the 1960s and 1970s, which was a rarity among ethnic minorities at the time. The text concludes with some examples of notable statistics in education, home ownership and famous Italian Canadians who indebted both Toronto and the rest of the country with their work.
\end{abstract}

\section{Keywords}

Italians, Toronto, immigration, entrepreneurship, education.

\section{Introduction}

As a New World country, Canada may be said to belong in the group of nations fundamentally shaped by immigration, whose waves have only periodically diminished, but have never actually ceased to exert their population dynamic

\footnotetext{
*sergej.macura@fil.bg.ac.rs
} 
onto the ever-shifting structure of society in the receiving land. This paper has for its goal a simple survey of Italian migratory trends in Canada since their beginnings, and some additional focus on the Italian immigrant community in Toronto from the post-World War II period to the present day, broadly taken as the postmodern age.

In short, mass Italian immigration to Canada can be divided into three major periods: from the 1870s to circa 1914; from 1920 to 1930; and from 1948 to approximately 1970 . The migration in the first two periods was stimulated by the National Policy, an economic programme aimed at the development of the Canadian home market, which the Conservative government implemented in 1879 and the later Conservative and Liberal governments supported. Since the country sorely needed reconstruction after World War II, which entailed mass immigration as a corollary, the Liberal policy opened up the path for a considerable increase in Italian numbers during the 1950s and 1960s. In addition, the 1924 Johnson-Reed Act in the US drastically cut the total number of immigrants allowed in each year and effectively cut off all immigration from Asia. It made permanent strict quotas - defined as "two percent of the total number of people of each nationality in the United States as of the 1890 national census" - in order to favour immigrants from northern and Western Europe and preserve the homogeneity of the nation. Therefore, the influx of hopeful immigrants invariably shifted to the north for several decades, and Canada admitted proportionally many times more inhabitants than its incomparably more densely populated southern neighbour (Zucchi 1994: 369, Diamond 2020: par. 2). As far as the post-1970s trends are concerned, the bulk of immigrants shifted noticeably to the newcomers from the Asian continent, like China, India, Vietnam, the Philippines and similar countries. Tremendous recent growth of immigrants from non-European countries of birth, many judged to be and labelled as non-white, makes the recent and current immigration boom substantially different from the immediate post-World War II expansion and other lesser peaks in the 1960s and 1970s, which is propelling Canada inexorably towards a complex multiracial future (Mercer 1995: 183-184).

According to Gabriele Scardellato, the inhabitants of the first Italian settlement in Toronto, now known as College Street Little Italy, began to arrive in its vicinity almost at the very beginning of the mass migration and immigration of Italians to the city. Immigrants from Italy have been present in Toronto from the early days of the city's history, but a large population of Italian origin did not emerge until the turn of the $19^{\text {th }}$ and $20^{\text {th }}$ centuries. By the late $1890 \mathrm{~s}$ emigration rates from Italy reached unheard-of levels as Italians fled in increasing numbers from the widespread phenomenon they referred to as miseria: the social and economic misery for which they could see no local solutions. Over 75 per cent of Italian immigrants to Canada came from the rural south of Italy, 
especially from Calabria, Abruzzi, Molise and Sicily, each with over $10 \%$ of the total. About three-quarters of these immigrants were small-scale farmers or peasants. Unlike northern Italy, which dominated the newly formed Italian state and continued to industrialise, southern Italy remained rural and traditional. Overpopulation, the fragmentation of peasant farms, poverty, poor health and inauspicious educational conditions, heavy taxation and political dissatisfaction acted as a "push" towards emigration (Sturino 2019: par. 9). At the beginning of the $20^{\text {th }}$ century annual migration rates occasionally totalled more than half a million in a population of about 33 million (Scardellato 2007: 11). The very name "Little Italy" in fact derives from external, not original ethnic experience, as the newcomers to the 2-square-kilometre downtown area bordered roughly by Bathurst, Dundas and Harbord Streets and Ossington Avenue did not sometimes find the warmest of receptions from the dominant Anglophone Canadians; even nowadays can it sound a little exotic and even diminishing, having in mind all the layers of history accumulated over the past century or so, and with many immigrant groups of a "farther" background than these South Europeans were first seen to demonstrate in contact with the majority population of prevalently British roots.

Large numbers of first-wave Italian immigrants were not desirable to the government eager to attract Ukrainians, in a dearth of Germans and Scandinavians, in the words of Minister of the Interior Clifford Sifton: "A stalwart peasant in a sheepskin coat with a stout wife and ten children." The railways which were tasked with the immense labour on the western prairies developed their own immigration programmes based on their own needs. On the one hand, they supported the government population programme because the railways had been given magnificent land concessions. On the other hand, the railways needed continuous reserves of labour for railroad construction, maintenance, and their subsidiary companies, especially in British Columbia and Alberta, in coal and hardrock mines and for smelting operations (Zucchi 1994: 370). Apart from gruelling manual labour in the almost uninhabited rural zones, a significant number of Italians during the same period opted for the urban economy. Some of them were channeled in that direction upon arrival from Italy, whereas others arrived there through the sojourning path, i.e. they meant to stay in Canada only temporarily. As John Zucchi notes, these Italians were generally small entrepreneurs and artisans such as fruit traders, hawkers, musicians, knife grinders, tailors, carpenters, masons, brickmakers, cobblers or bakers (Zucchi 1994:371).

\section{Foundations for the Next Waves}

From their first migrations to Toronto, Scardellato writes, the Italians developed a relatively complex pattern of settlement based on factors like their villages, 
towns or provinces of origin in Italy, the economic niches they were able to fill in the city, and their proximity both to places of work and to transportation facilities. The result, by the early years of the $20^{\text {th }}$ century, was a group of at least four main settlement areas: the largest and the most important, in the area of the city then known as the Ward, a name derived from St John's Ward, one of the early districts bounded by College and Queen Streets to the north and south respectively; the second, further north and to the west of the Ward in the neighbourhood of Dufferin Street near Davenport Avenue (over time this settlement expanded westward to the West Toronto Junction); the third neighbourhood, somewhat smaller than these two, developed to the east of the Ward, around the intersection of Queen Street East and Parliament Street; and the fourth settlement area, also relatively near the Ward, bounded by College and Dundas Streets on the north and south respectively, the original heart of College Street Little Italy, from which grew the post-World War II heart of the so-called Toronto Italia (Scardellato 2007: 12).

During the second wave of Italian immigration to Canada, the numbers of newcomers rose rapidly in the 1920s. Canada experienced an economic boom in the period from 1924 to 1929 , one strongly fuelled by resource exports, pulp and paper, forestry, precious and industrial metals, as well as manufacturing, in particular, automobiles. In the space of just a few years, 40,000 Italian immigrants arrived in Canada. Some worked as farm laborers, others entered the building trades in small and large cities, but the majority worked in the railways, and in the mining and paper industry as well. The children of prewar immigrants were now entering the work force, some of them moving into the professions and most of them into industry (Zucchi 1994: 371). The quotas fell sharply in the 1930s for several reasons: the Canadian government's restrictions, Mussolini's 1928 ban on departures from Italy and the Great Depression which spread from the US (Scardellato 2007: 14). In sum, the Toronto population with Italian origins grew from about 1,000 in the 1890 s to 4,900 in 1911, to 9,000 in 1921, to 20,000 in 1940 , when the Italian Canadians were declared "enemy aliens" and some were even interned; after the bilateral laxing of measures in 1945, a true boom followed in the 1951-1970 period, when the numbers skyrocketed from 60,000 to 270,000 in the officially designated Toronto Census Metropolitan Area (Troilo 2011: 9; Ornstein 2006: 14). A lull ensued in the 1970s and 1980s due to the efficient revitalisation of the Italian economy and the abolition of sponsored immigrant status, so the 2001 census shows the figure of about 325,000 Italians in the same area (Ornstein 2006: 14), which has not oscillated too much to the present day. 


\section{After World War II}

World War II made an end to unemployment, but it contributed to the housing crisis, since the rapid increase in population was not matched by dwelling construction. The number of inhabitants in the city increased by 190,000 , but on the other hand, fewer than 44,000 new housing units were constructed from 1931 to 1947 . The dismal situation with scarce state-assisted housing to immigrants continued well into the 1970s, somewhat due to the lack of governmental initiative, somewhat owing to the landlords' uncontrolled rental policies. The Italians and the Portuguese adopted an approach different from many others who hoped for state subsidies and lodged applications for public housing. Using their time-proven close-knit ethnic neighbourhood policies, they relied on extensive family ties and great economic sacrifice to become house owners; often they borrowed private money, rented out a part of the owned house in order to pay the mortgage, cohabitated with other families on relatively small premises and invested large sums of money to be able to make the home purchase. In addition, women's paid labour formed part of the well-articulated family strategy for achieving success. This ethnic group laid much emphasis on measuring emigration success in terms of owning a house or a flat several years into their stay abroad, unlike many other communities with different sets of values (Purdy 2003: 460, 463). As a commendatory illustration of Italian adaptability, they fared better even in comparison with the Atlantic Canadians who migrated to Toronto and experienced a sort of cultural shock: pockets of these "invisible immigrants" were located in Regent Park, and among the most vulnerable were males displaced from the agricultural, fishing, forestry, and mining sectors and who were unable to easily adjust to the urban, service economy. British and Italian immigrants to Toronto were decribed as "better prepared for the transition period" than many Maritimers (Marquis 2010: 90). Data from 1986 demonstrate that the home ownership rates are the highest among the Italian population in overall Canada (83\%), whereas the general average is only $58 \%$. One of the reasons is that certain ethnic groups, like the Italians and the Chinese consider real estate ownership a value in itself, not just an investment for the future financial transactions. It is still not completely clear what exact factors cause these results, but it can be safely assumed that the earlier the period of immigration, the higher the ownership - earlier immigrants are probably older and they have accumulated enough money to purchase properties in the few decades of their headstart. Also, the size of an ethnic group matters because there exist various inner institutions organised among a higher number of individuals (Balakrishnan and Wu 1992: 391, 400-401), which can be exceptionally helpful in the case of long-term loans, collective house-building actions, communal living, etc.

To illustrate the rise in Italian influence on the economic sector in Canada, we supply a table which demonstrates the decades of arrival and the number of 
founded companies on a small sample: the majority of entrepreneurs immigrated in the 1950-1969 period and established their companies over the following twenty years, that is, between 1970 and 1989 .

Table 1. Periods of Italian entrepreneurs' arrival in Canada and the foundation of companies (on a sample of 120 businesses)

(Troilo 2011: 12-13)

\begin{tabular}{|c|c|c|}
\hline Period & Arrivals & Founded companies \\
\hline Before 1940 & 11 & 5 \\
\hline $1940-49$ & 3 & 0 \\
\hline $1950-59$ & 45 & 11 \\
\hline $1960-69$ & 32 & 13 \\
\hline $1970-79$ & 5 & 24 \\
\hline $1980-89$ & 3 & 30 \\
\hline $1990-99$ & 1 & 16 \\
\hline $2000-06$ & 0 & 1 \\
\hline
\end{tabular}

In the 1960s, a majority of Italian immigrants would have originated in the rural south of Italy, so it is not surprising to find that they had a low educational level. A rank order correlation of census tracts by ethnic origin and elementary school only revealed that Italians had a coefficient of 0.76 . Almost a quarter (23.4\%) of Italians in Toronto in 1961 spoke no English at all, far below any other ethnic group's percentage of under $10 \%$. This low level of education is reflected in types of occupations and average incomes. Two-thirds (67.4\%) of Italian males were classified as labourers or craftsmen in the 1961 census. Only 7.9\% (compared to a Toronto average of $24.8 \%$ ) were in managerial or professional occupations. The Italians with high status jobs appear to have been born in Canada (of Italian origin parents) for, among those born in Italy only $4.2 \%$ were in managerial and professional while almost three quarters $(73.2 \%)$ were in labourers or craftsmen occupations. Of all ethnic groups, both male and female Italians had the lowest average incomes $(\$ 3,189$ males and $\$ 1,592$ females), about $60 \%$ of the Toronto rate (Jansen 1969: 28-29). Great strides were made by Italian Canadians in the field of education, as reflected in post-secondary statistics. By the mid-1980s, the percentage of Canadian-educated Italians (Canadian-born and those who emigrated before age 15) with a university degree was above the $10 \%$ mark, which represented the total population. Over one-quarter had a community college education, 3\% more than overall. Over $7 \%$ of male Italian Canadian 
students were enrolled in the professional fields of law, dentistry and medicine (which was on a par with the average for all groups) and had one of the highest proportions embarking on graduate studies (Sturino 2019: par. 26).

\section{The Construction Sector and Women's Labour}

One of the reasons for the prominent status enjoyed by the Italians in Toronto nowadays lies in the post-World War II social climate and the then labour market: many more than one-half of the Italian immigrants were men, they as a rule had a lower educational level than most members of the same age group, and the booming city was expanding its boundaries on an unprecedented scale. First of all, the newcomers arrived as paesani, not as Italians, and so they did not even feel they belonged to the same community. As many first-generation Italian immigrants recalled, they were Sicilians or Calabresi or Friulani, who had never met before, and they did not understand each other. On their arrival, Italian hometown belongings represented the immigrants' identities more than any sort of Italianity (Agnoletto 2014: 114). The logic of chain migration also enforced the establishment of Italian labour niches because they meant that many immigrants found employment through relatives or friends, thus forming concentrations in particular industries and companies. For example, in addition to the construction field, Italians formed "paese" concentrations in such concerns as the Christie Brown Bread Company and Bomac Steel, or smaller firms like Beverley Bedding (Agnoletto 2014: 117). A correspondence became prominent between the boom of the construction industry and the influx of Italian immigrants into Toronto. During the 1950s a high demand for male labour met with the supply of Italian workers in the Toronto construction market: moreover, the particular nature of construction work fitted the characteristics and needs of the new immigrants from Italy. The sector offered many opportunities to immigrants with few industrial skills and little formal education and so "greenhorns quickly snapped up seasonal jobs digging foundations, carrying materials, pushing wheelbarrows, mixing cement, and helping more experienced tradesmen" (Agnoletto 2014: 164).

In particular, female labour implied a sort of social stigma for the men in the families, because "the men were not able to provide for the family" and so forced the wives to work. Simultaneously, the choice for the wife to work was often part of a well-articulated and agreed working-class family strategy of social mobility, as support for the family during the periods of seasonal male unemployment that were typical of the construction industry (Agnoletto 2014: 123). 
Italians had begun with small jobs, such as waxing stairs and porches, and then they built palaces. Crucial elements of their initial success were both the Italian networks and the hunger for "Italianity": they realised that the Italian community required Italian builders, so they found partners, often non-Italians, with the capital, and they put an Italian name on the company, so the potential Italian buyers could trust them. The history of Italian employers in the post-WWII Toronto construction industry is summed up in three words: "lavoro, sacrificio e fortuna [work, sacrifice and luck]" (Agnoletto 2014: 184). As far as sacrifice is concerned, these workers initially worked in a combination of exploitation and illegality, while manifesting business abilities and hardworking attitudes. The success of many Italian companies was the result of a readiness to sacrifice and of entrepreneurship attitudes, the so-called ambition to set up one's own business shown by many Italian immigrants. At the same time, many workers remember that the contractors exploited the paesani like beasts from sunrise to sunset and so "noi italiani lavoravamo come muli [we Italians worked like mules]" (Agnoletto 2014: 173). During the 1960s and 1970s, the Italian construction workers succeeded in securing their elementary labour rights through the newly established trade unions, which to some became second families, where they could voice their concerns and strengthen their job security; in this manner, the employers had to work for the labourers, not the other way round.

Despite all the traditional prejudices that acted as hindrances to the Italian women's development and integration into the new environment, it was mostly their efforts which transformed peasant families into working-class households, in a dialectical relationship with their roots from an evidently patriarchal system of values. By the early 1970s, the struggle of Italian Canadian women for their rightful place in the family as equal breadwinners as the men had finally yielded fruit in their increased employment in the cases of husbands injured at work; the role of the leader underwent changes, as did the authority figure (Storey 2009: 89). Although there was a lot of discrimination and barely shrouded resistance to the working immigrant women, the labour movement managed to influence the government so successfully that the Workers' Compensation Act was amended in 1984 and the lifetime pensions for disabled workers were retained, with the novelty in the form of lifetime pensions given to the orphans and widows of killed workers (Storey 2009: 92).

\section{The Present Day}

Nowadays the numbers of Italians immigrating to Canada have been reduced to a trickle, averaging from 500 to 1,000 since 2006 , and other ethnic groups, most notably from Asia, have filled in the former Italian spot as the largest non-British group of immigrants to the country. Due to the process known as 
the brain drain, we can notice that the weight of the higher titles (masters and doctorates) increased in a significant way from 1980 to 2002, a trend noticeable also at the EU level, but with lower variations regarding the doctorate titles. It seems that highly qualified professionals moved looking for a new dynamic economic world where people can monetise the titles obtained in their home country, or to enrich their own résumé at a Canadian university, or work in highly demanded trades, such as pharmaceutics, engineering or information technology (Cecchinato 2012: 46-47).

According to the 2016 census, the present-day territory in Toronto with significant numbers of Italian speakers, or with persons claiming full or partial Italian origin, has dispersed from the relatively solid wedge that extended from the downtown and harbour neighbourhoods and about $15 \mathrm{~km}$ to the northwest - nowadays we can find Italian spoken mostly in York, North York and Etobicoke, with the remaining pockets in Old Toronto, shaded darker than the other territorial units.

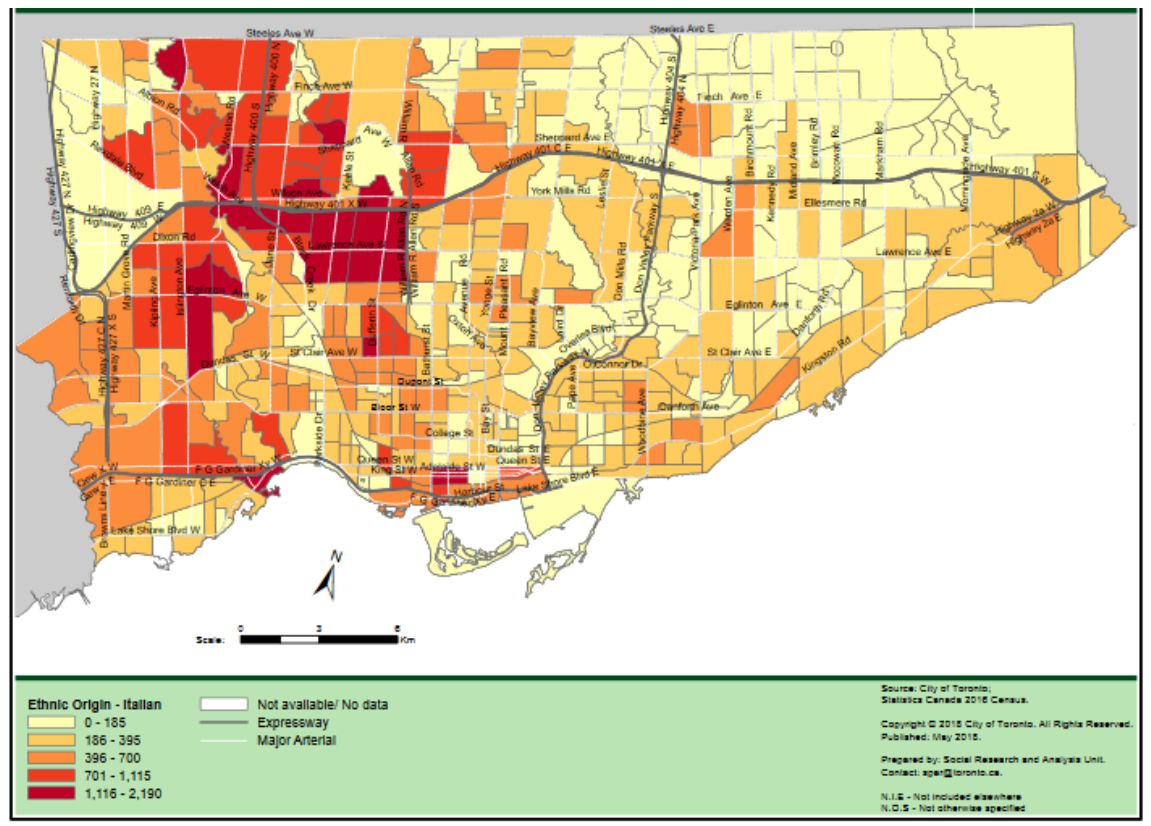

Fig. 1. Italian language distribution in the 2016 Toronto census

Finally, out of a vast group numbered in the thousands, we could mention just a handful of Italian Canadians who have left an indelible trace on the vibrant life in the New World community with their aspirations, hard work and notable achieved results. They include: Alessia Cara, Grammy Award-winning singer 
and songwriter, creator of some of the most popular pop hits of the 2010s; Anne Marie DeCicco-Best, the longest-serving mayor of London, Ontario (from 2000 to 2010), and a professor of public relations at Fanshawe College; Johnny Lombardi, who promoted Italo-Canadian musicians and spent 50 years in multicultural broadcasting, earning the status of a legend at the CHIN Radio, the first of the kind in Ontario; Sergio Marchionne, who revived Fiat and Chrysler from the brink of an economic collapse and helped them report profits surprisingly soon; Frances Nunziata, a Toronto City councillor for one of the two York neighbourhoods (Ward 5), concerned mostly with issues of law and order; Anthony Perruzza, a member of the Toronto City Council and a longtime supporter of tenant rights and transportation improvements; Tony Rizzo, a York councillor and an Ontario legislator, who often worked hard for better transportation in the metropolitan area; Claudio Polsinelli, a councillor of North York, also a member of the Provincial Parliament, Treasurer of Ontario and Minister of Economics; and Nino Ricci, acclaimed writer who has won Canada's most prestigious prizes, like the 1990 and 2008 Governor General's Award for Fiction, the 2002 Trillium Book Award, and the 2011 Order of Canada - Lives of the Saints (1990) and The Origin of Species (2008) being the most aclaimed works he has authored.

\section{WORKS CITED}

Agnoletto, Stefano. The Italians Who Built Toronto: Italian Workers and Contractors in the City's Housebuilding Industry, 1950-1980. Oxford, Bern, Berlin: Peter Lang, 2014.

Balakrishnan, T. R, and Zheng Wu. "Home Ownership Patterns and Ethnicity in Selected Canadian Cities". The Canadian Journal of Sociology / Cahiers canadiens de sociologie, 17.4 (1992), 389-403.

Cecchinato, Elisa. Escape from Italy: The Italian Immigration Experience in Canada from the Unification of Italy to the Present Day. Unpublished M.A. thesis. Università Ca' Foscari, Venice, 2012. Online: http://dspace.unive.it/ bitstream/handle/10579/1686/802497-1154004.pdf?sequence $=2$ [accessed 7 November 2019].

Diamond, Anna. "The 1924 Law That Slammed the Door on Immigrants and the Politicians Who Pushed it Back Open". The Smithsonian Magazine (19 May 2020). Online: https://www.smithsonianmag.com/history/1924law-slammed-door-immigrants-and-politicians-who-pushed-it-backopen-180974910/ [accessed 16 July 2020].

Jansen, Clifford J. "Leadership in the Toronto Italian Ethnic Group". The International Migration Review, 4.1 (1969), Immigration in Canada, 25-43. 
Marquis, Greg. “Confederation's Casualties: The 'Maritimer' as a Problem in 1960s Toronto". Acadiensis, 39.1 (2010), 83-107.

Mercer, John. "Canadian Cities and Their Immigrants: New Realities". The Annals of the American Academy of Political and Social Science, 538 (1995), Being and Becoming Canada, 169-184.

Ornstein, Michael. Ethno-Racial Groups in Toronto, 1971-2001: A Demographic and Socio-Economic Profile. Toronto: Institute for Social Research, York University, 2006. Online: http://www.isr.yorku.ca/download/Ornstein--Ethno-Racial_Groups_in_Toronto_1971-2001.pdf [accessed 6 March 2019].

Purdy, Sean. “'It Was Tough on Everybody”: Low-Income Families and Housing Hardship in Post-WorldWar II Toronto". Journal of Social History, 37.2 (2003), 457-482.

Scardellato, Gabriele. "A Century and More of Italians in Toronto: An Overview of Settlement”. Quaderni d'italianistica, 28.1 (2007), 7-31.

Statistics Canada 2016 Census. Online: https:/www.toronto.ca/wp-content/uploads/2018/06/972f-ct16_TOR_EthnicOrigin_Italian.pdf [accessed 3 March 2019].

Storey, Robert. "From Invisibility to Equality? Women Workers and the Gendering of Workers' Compensation in Ontario, 1900-2005". Labour / Le Travail, 64 (2009), 75-106.

Sturino, Franc. "Italian Canadians". The Canadian Encyclopedia (2019). Online: https://www.thecanadianencyclopedia.ca/en/article/italian-canadians [accessed 11 October 2019].

Troilo, Matteo. "Lavoro ed imprenditoria degli italiani in Canada, tra vecchie e nuove generazioni". Diacronie: Studi di Storia Contemporanea, no. 5 (2011). Online: http://www.studistorici.com/2011/01/29/troilo_numero_5/ [accessed 17 February 2020].

Zucchi, John. "The Italian Immigrant Presence in Canada, 1840-1990". Tomasi, Lydio; Gastaldo, Piero; Row, Thomas (eds.). The Columbus People: Perspectives in Italian immigration to the Americas and Australia (368-340). New York: Center for Migration Studies, 1994. 